\title{
FAKTOR-FAKTOR YANG MEMPENGARUHI STATUS GIZI ANAK BALITA DI KABUPATEN TIMOR TENGAH UTARA, PROVINSI NUSA TENGGARA TIMUR
}

\author{
(Factors Influencing Nutritional Status of Underfive Children in Timor Tengah Utara District, \\ Nusa Tenggara Timur Province)
}

\author{
Hadi Riyadi ${ }^{1 *}$, Drajat Martianto ${ }^{1}$, Dwi Hastuti ${ }^{2}$, Evy Damayanthi ${ }^{1}$, dan Kukuh Murtilaksono ${ }^{3}$ \\ 1 Departemen Gizi Masyarakat, Fakultas Ekologi Manusia, Institut Pertanian Bogor, Bogor 16680. \\ 2 Departemen Ilmu Keluarga dan Konsumen, Fakultas Ekologi Manusia, Institut Pertanian Bogor, \\ Bogor 16680. \\ 3 Departemen Ilmu Tanah dan Sumberdaya Lahan, Fakultas Pertanian, Institut Pertanian Bogor, \\ Bogor 16680. \\ * Alamat korespondensi: Departemen Gizi Masyarakat, Fakultas Ekologi Manusia, Institut Pertanian \\ Bogor, Bogor 16680. Telp: 0251-8621258; Fax: 0251-8622276; Email: hadiriyadi@gmail.com
}

\begin{abstract}
This research aims to analyze underlying factors affecting child malnutrition at Timor Tengah Utara district, NTT. The design was a cross-sectional study. Sample of this study was household that have underfive years old children residing in the areas of Plan International. Data was collected by using structured questionnaire, focus group discussion and in-depth interview. Nutritional status was measured using anthropometric measurement with weight and height indicators and child consumption was recorded using 24 hours food's recall. Result showed that in three villages prevalence of malnourished children was high, which were $6.0 \%$ classified as severe underweight, $15.3 \%$ severe stunting and $0.7 \%$ severe wasting. There was no significant difference in term of nutritional status. Child malnutrition was influenced by low access to nutrition and health information, low nutrition knowledge and practices, and low family income.
\end{abstract}

Key words: underfive children, nutritional status, Timor Tengah Utara

\section{PENDAHULUAN}

Permasalahan gizi anak balita di Timor Tengah Utara masih cukup tinggi, hal ini terlihat dari prevalensi gizi kurang dan buruk (underweight) yang mencapai 37.5 persen, prevalensi pendek (stunting) 59.6 persen dan prevalensi kurus (wasting) 16 persen (Depkes RI, 2008). Keadaan tersebut menunjukkan anak balita masih menderita masalah gizi akut dan kronis. Gizi kurang pada anak balita dapat mempengaruhi perkembangan fisik dan kecerdasan. Berdasarkan studi sebelumnya di Lembata, Provinsi Nusa Tenggara Timur (NTT) terlihat bahwa bahwa terdapat keragaman status gizi menurut umur. Anak yang masih menerima ASI atau ASI eksklusif pada umumnya tidak mengalami kekurangan gizi. Gizi kurang banyak ditemukan pada bayi umur 6 bulan ke atas. Sementara berdasarkan gender, anak perempuan lebih banyak menderita gizi kurang daripada anak laki-laki (Martianto et al., 2006).

Gizi kurang, kematian dan kecacatan fisik maupun rendahnya kecerdasan pada anak dipengaruhi oleh faktor langsung dan tidak langsung (Myers, 1990; Zeitlin et al., 1991; Engel, Mennon \& Haddad, 1997) sebagaimana diperlihatkan pada kerangka model UNICEF. Dua faktor langsung pada model tersebut adalah kurangnya konsumsi makanan dan kondisi kesehatan, sedangkan faktor tidak langsung adalah ketahanan pangan, pengasuhan dan akses kepada sarana kesehatan dan kondisi lingkungan dimana anak tinggal. Penelitian ini ingin menganalisis faktor-faktor yang mempengaruhi status gizi di Kabupaten Timor Tengah Utara, Propinsi Nusa Tenggara Timur.

Guna mengetahui penyebab terjadinya gizi kurang pada anak balita di Kabupaten Timor Tengah Utara (TTU), beberapa pertanyaan diajukan dalam penelitian ini, mencakup: 1) karakteristik keluarga; 2) akses ibu terhadap sarana dan pelayanan kesehatan (Posyandu, Puskesmas dan sebagainya) serta akses keluarga terhadap air bersih dan sanitasi lingkungan; 3) pola asuh keluarga; 4) kebiasaan, distribusi dan prioritas makan dalam keluarga, termasuk kecukupan zat gizi anak balita; 5) perilaku hidup sehat anak balita; serta 6) keberadaan penyakit infeksi (diare, ISPA dan sebagainya). 


\section{METODE}

\section{Desain dan Lokasi}

Disain yang digunakan adalah cross sectional study. Penelitian dilakukan di Kabupaten TTU. Penelitian dilakukan di tiga desa, yaitu Desa Sekon, Desa Banain dan Desa Tokbesi, Kabupaten Timur Tengah Utara (TTU). Pemilihan lokasi didasarkan atas pertimbangan: 1) termasuk dalam wilayah kerja PLAN; 2) prevalensi anak balita gizi kurang cukup tinggi; serta 3) memiliki keragaman akses pangan yang bervariasi, yaitu terdekat ke perkotaan (Desa Sekon), cukup/sedang (Desa Banain) dan jauh ke perkotaan (Desa Tokbesi).

\section{Cara Pemilihan Sampel}

Populasi pada penelitian ini adalah keluarga yang tinggal di daerah intervensi PLAN INDONESIA. Kerangka sampel adalah keluarga dengan anak balita di lokasi terpilih, dan unit sampel adalah anak balita pada keluarga terpilih. Survei pendahuluan dilakukan untuk melakukan sampling, yang akan mengelompokkan keluarga yang memiliki anak balita. Selanjutnya, dilakukan acak sedehana sejumlah minimal 10-15 persen sampel dari kerangka sampling. Akhirnya didapatkan sampel masingmasing sebanyak 49 keluarga di Desa Sekon, 50 keluarga di Desa Banain dan 50 keluarga di Desa Tokbesi, sehingga total sampel sebanyak 149 keluarga dengan anak balita.

\section{Jenis dan Cara Pengumpulan Data}

Data primer dikumpulkan dari keluarga terpilih (sampel) meliputi keadaan sosial ekonomi rumah tangga, keadaan sanitasi dan higienis, praktek gizi, pola pengasuhan, praktek makan anak, konsumsi pangan anak dan antropometri anak. Data sosial ekonomi rumah tangga, keadaan sanitasi dan higienis, praktek gizi, pola pengasuhan, praktek makan anak dikumpulkan melalui wawancara dengan menggunakan kuesioner terstruktur. Disamping itu pengumpulan data di tingkat keluarga dilakukan juga melalui focus group discussion (FGD), Pengukuran status gizi dilakukan dengan mengukur berat badan dan panjang badan/tinggi badan anak balita menggunakan timbangan injak dan alat ukur panjang/tinggi badan. Konsumsi pangan anak balita dikumpulkan dengan metode 24 hours recall.

\section{Pengolahan dan Analisis Data}

Kategori status gizi ditentukan berdasarkan indikator $\mathrm{BB} / \mathrm{U}, \mathrm{TB} / \mathrm{U}$ dan $\mathrm{BB} / \mathrm{TB}$ dengan menggunakan z-skor berdasarkan stadar antropometri WHO 2006. Anak balita dengan z-skor $<-3$ sd dikategorikan gizi buruk, -3sd hingga 2sd dikategorikan gizi kurang dan > -2sd hingga +2sd dikategorikan gizi normal (WHO, 1995). Skoring digunakan untuk mengklasifikasikan pengetahuan gizi ibu, kebiasaan dan konsumsi pangan, serta praktek pengasuhan dan kesehatan. Data konsumsi pangan diolah untuk melihat kualitas konsumsi pangan anak balita. Analisis korelasi digunakan untuk menentukan hubungan dan sifat hubungan antar faktor yang berhubungan dengan gizi kurang pada anak balita. Flower Model diaplikasikan untuk mengidentifikasi penyebab masalah gizi kurang di daerah penelitian.

\section{HASIL DAN PEMBAHASAN}

\section{Karakteristik Keluarga}

Pada ketiga desa umumnya umur orang tua berada pada kisaran 25-35 tahun dengan rata-rata umur ayah 37 tahun dan ibu 32 tahun. Persentase tertinggi ayah dan ibu $(64.6 \%$ dan $71.2 \%$ ) hanya berpendidikan SD dengan rata-rata lama pendidikan adalah 7 tahun. Separuh keluarga termasuk kategori keluarga sedang dengan rata-rata jumlah anggota keluarga 5 orang.

Lebih dari separuh keluarga (63.3\%) memiliki situasi sosial ekonomi yang cukup dengan skor rata-rata 7.5 (skor total 12). Pada umumnya keluarga memiliki pendapatan total dibawah Rp 500.000 per bulan (87.3\%), memiliki rumah sendiri (78.5\%), memiliki lahan (91.3\%), memiliki minimal dua aset (61.3\%), dan anggota keluarga memiliki keterampilan bertani $(94.7 \%)$, namun sebanyak 61.3 persen ibu menyatakan bahwa akses ke pasar relatif jauh dan mahal, terutama di Desa Banain dan Desa Tokbesi.

Sebagian besar (56.0\%) memiliki pengeluaran total per kapita per bulan berkisar antara Rp 50.000-Rp 100.000 dengan rata-rata pengeluaran sebesar Rp 93.000/kapita/bulan. Rata-rata pengeluaran keluarga untuk pangan (Rp 59.900) relatif lebih besar daripada ratarata pengeluaran untuk non pangan (Rp 33.200). Rata-rata pengeluaran pangan paling rendah terdapat di Desa Sekon (Rp 55.700) yang sebagian besar dialokasikan untuk beras atau makanan pokok.

Para ibu di ketiga desa hampir seluruhnya (94-98\%) telah mendengar informasi gizi dan kesehatan, namun masih terbatas dari 
posyandu atau sekolah, sedangkan sumber informasi lainnya, seperti koran, radio atau tenaga kesehatan belum banyak berperan. Oleh karena itu, akses ibu terhadap informasi dan pelayanan gizi dan kesehatan dinilai masih kurang $(86.7 \%)$ dan paling banyak terdapat di Desa Tokbesi (98.0\%). Alasan ibu datang ke posyandu sebagian besar hanya untuk menimbang bayi atau anak balitanya.

Lebih dari 50 persen ibu rata-rata memiliki skor pengetahuan gizi kurang dan paling banyak terdapat di Desa Tokbesi (66.0\%). Hasil uji korelasi menunjukkan bahwa tingkat pengetahuan gizi ibu berhubungan positif dan signifikan dengan pendidikan ibu $\left(r=0.243^{* *}\right)$. Hasil ini sejalan dengan penelitian Myers (1990) tentang hubungan antara pendidikan dan pengetahuan gizi ibu, termasuk akses ke pelayanan gizi dan kesehatan.

\section{Akses Keluarga terhadap Air Bersih dan Sanitasi Lingkungan}

Jika keadaan lingkungan fisik dan sanitasi keluarga baik, maka kondisi kesehatan penghuni rumah tersebut juga akan baik, demikian pula sebaliknya. Sumber air untuk memasak atau minum pada umumnya berasal dari mata air dan sumur umum. Selama kebersihan sumur dan mata air terjaga dengan baik, peluang sumber air ini menyebarkan penyakit menular sangat kecil. Keberadaan MCK juga sangat penting, khususnya untuk mencegah berkembangnya penyakit diare dan cacingan. Sebagian besar keluarga sudah memiliki MCK sendiri (95.3\%), namun ketersediaan air bersih menjadi masalah serius, terutama saat musim kemarau.

Jenis dinding rumah yang terbanyak ditemukan berupa bilik/bebak pada 76.7 persen keluarga. Jenis lantai rumah sebagian besar (71.3\%) berupa tanah. Kondisi ini menunjukkan cukup tingginya resiko penyakit, seperti cacingan dan ISPA karena debu. Sampah pada umumnya $(72.7 \%)$ diperlakukan dengan cara dikumpulkan di lubang dan kemudian dibakar. Sebanyak $38.7 \%$ rumah tidak memiliki ventilasi yang memadai, sehingga sirkulasi udara di rumah kurang terjamin. Rendahnya pencahayaan di sebagian besar (69.3\%) rumah menambah parah keadaan ini. Selain itu, adanya kandang ternak dengan jarak kurang dari 10 meter tentunya kurang ideal dari sisi kesehatan (61.8\%).

Di samping itu, masyarakat Kabupaten TTU memiliki kebiasaan yang tidak baik, yaitu meludahkan bekas menginang sirih ke lantai rumah. Hewan peliharaan, terutama anjing, juga bebas berkeliaran di dalam rumah. Hasil analisis menunjukkan bahwa lebih dari 50 persen keluarga di daerah penelitian tidak memiliki lingkungan fisik dan sanitasi memadai.

\section{Praktek Gizi dan Kesehatan}

Praktek gizi dan kesehatan dalam penelitian ini mencakup kebiasaan ibu dalam membawa anak ke posyandu, kepemilikan KMS, kebiasaan mencuci tangan dengan sabun, serta mencuci bahan makanan dan peralatan masak. Pada Gambar 1 tampak bahwa sekitar 77 persen responden melakukan praktek gizi dan kesehatan dalam kategori baik. Jika dibandingkan antar desa, maka ibu di Desa Tokbesi memiliki praktek gizi dan kesehatan paling banyak tersebar pada kategori baik.

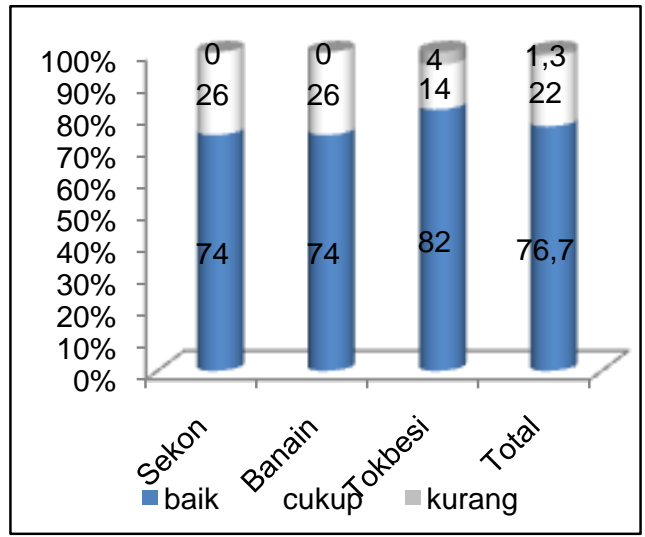

Gambar 1. Sebaran Ibu menurut Kategori Praktek Gizi dan Kesehatan

Berdasarkan jenis praktek gizi dan kesehatannya, tampak masih ditemukan sebanyak 30.7 persen ibu yang tidak membawa anak balita ke posyandu sejak lahir. Oleh karena itu, kader posyandu maupun bidan desa harus dapat memotivasi lebih baik lagi partisipasi ibu ke posyandu. Selain itu, tingginya persentase anak balita (23.3\%) yang tidak pernah mencuci tangan sabun secara tidak langsung menunjukkan kelangkaan air di tingkat keluarga dan keterbatasan sumberdaya uang untuk membeli sabun.

\section{Praktek Pengasuhan Psikososial}

Pengasuhan ibu kepada anak menunjukkan kemampuan ibu untuk memberikan stimulasi yang dibutuhkan oleh anak balita. Hasil penelitian menunjukkan terdapat sekitar 27 persen ibu yang memiliki kualitas pengasuhan dalam kategori kurang. Jika dibandingkan antar desa, maka ibu di Desa Banain memiliki 
skor praktek pengasuhan paling rendah daripada ibu di desa lain. Secara keseluruhan terlihat bahwa masih cukup banyak ibu yang melakukan kekerasan saat marah pada anak dengan mencubit, memukul, berkata negatif, dan sebagainya.

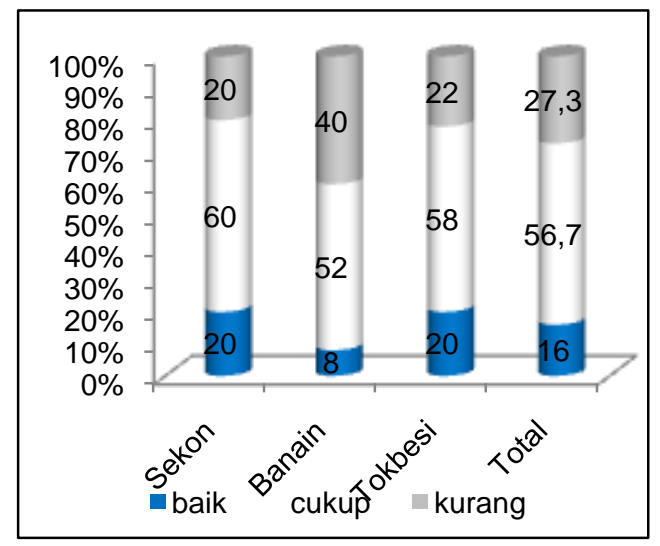

Gambar 2. Sebaran Ibu menurut Kategori Kualitas Pengasuhan Psikososial

Jika dibandingkan antar desa, maka ibu di Desa Sekon memiliki skor praktek paling tinggi daripada ibu di dua desa lain. Ibu di Desa Sekon lebih sering mengungkapkan kasih sayangnya dengan kata-kata dan belaian kepada anak, ibu dapat lebih menahan emosi dan tidak menunjukkan kemarahan kepada anak, serta lebih banyak menyediakan mainan atau buku-buku anak dan lebih lama menghabiskan waktu bersama anak setiap harinya.

\section{Praktek Makan Anak}

Studi tentang riwayat pemberian ASI dan kebiasaan makan anak menunjukkan ibu di Desa Sekon paling sedikit (22.2\%) memberikan ASI eksklusif, sebaliknya ibu di Desa Tokbesi paling banyak (63.3\%) yang memberikan ASI eksklusif. Di desa Sekon juga tercatat sekitar 6 persen anak memiliki kebiasaan minum susu secara teratur setiap hari, paling tinggi daripada desa lain. Bahkan ibu yang memberikan ASI hingga dua tahun hanya sebesar 37 persen. Berdasarkan temuan ini, kampanye ASI eksklusif perlu ditingkatkan. Makanan pendamping ASI mulai diberikan pada umur 4 atau 6 bulan. Makanan padat pertama adalah pisang lumat/ bubur saring/bubur tepung beras/bubur tepung jagung dengan frekuensi makan umumnya adalah tiga kali (70\%), namun masih terdapat 9.3 persen anak yang hanya makan sekali dalam sehari. Jika dilihat berdasarkan skoring, skor praktek di Desa Sekon adalah paling rendah.

\section{Perilaku Hidup Sehat Anak}

Perilaku hidup sehat anak tergantung pada perilaku yang dicontohkan oleh ibu maupun lingkungannya. Sebagian besar (60.7\%) perilaku hidup sehat anak di daerah penelitian termasuk kategori kurang, dimana Desa Tokbesi menempati urutan tertinggi $(72.0 \%)$, diikuti Desa Banain (68.0\%) dan Desa Sekon (42.0\%). Hal ini karena lokasi Desa Sekon paling dekat dengan ibukota Kabupaten Kefamenanu, sehingga akses informasi dan ketersediaan sarana dan prasarana, termasuk air bersih lebih terdukung daripada desa lainnya (Gambar 3)

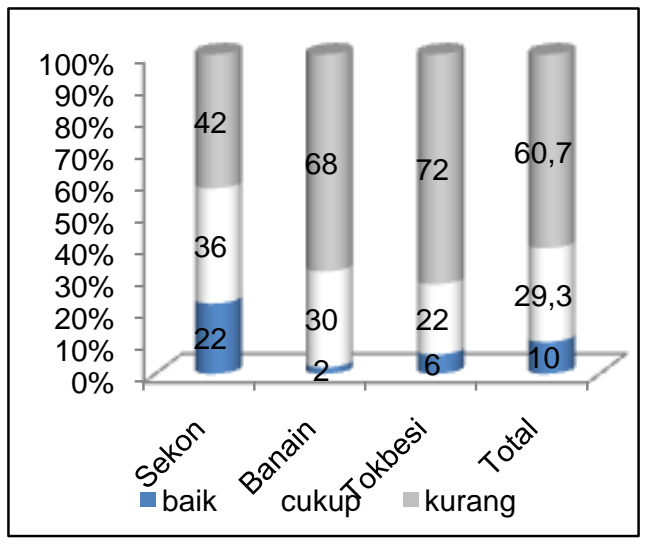

Gambar 3. Sebaran Anak Balita menurut Perilaku Hidup Sehat

Keterbatasan air bersih menghambat ibu dalam menerapkan perilaku hidup sehat bagi anak. Mencuci rambut dilakukan setiap kali mandi dengan cara sekaligus menyabuni badan dan rambut dengan sabun mandi. Kebiasaan mencuci tangan setelah buang air besar telah dilakukan oleh sebagian ibu menggunakan air saja dan sebagian lagi menggunakan sabun, sedangkan mencuci tangan sebelum makan kadang dilakukan oleh 50 persen anak. Kebiasaan mencuci kaki sebelum tidur juga masih jarang dilakukan.

\section{Asupan dan Tingkat Kecukupan Zat Gizi Anak}

Frekuensi makan anak ditampilkan untuk melihat pola kebiasaan makan anak di daerah penelitian. Makanan pokok masyarakat di ketiga desa adalah beras dan jagung, yang terlihat dari frekuensi konsumsi nasi lebih dari 1 kali per hari dan jagung lebih dari 3 kali per minggu. Kedua jenis makanan ini terkadang dicampur menjadi nasi jagung. Makanan sumber protein hewani yang biasa dikonsumsi anak adalah ikan dan telur, dengan rata-rata frekuensi konsumsi 1 kali per minggu. Sementara makanan sumber protein nabati, seperti tempe dan ta- 
hu, sangat jarang dikonsumsi. Frekuensi makan sayuran minimal 1 kali per hari, sedangkan frekuensi konsumsi buah-buahan pada umumnya kurang dari 1 kali per minggu dan hanya dikonsumsi pada musim buah tertentu. Susu juga jarang dikonsumsi karena harganya yang tidak terjangkau.

Tabel 1. Tingkat Kecukupan Zat Gizi Anak Balita

\begin{tabular}{lcccc}
\hline Jenis Zat Gizi & Sekon & Banain & Tokbesi & Total \\
\hline Energi & 74.6 & 79.4 & 74.2 & 76.1 \\
Protein & 51.4 & 49.8 & 61.7 & 57.8 \\
Lemak & 13.7 & 15.4 & 22.9 & 17.3 \\
Kalsium & 15.7 & 11.2 & 16.1 & 14.3 \\
Fosfor & 38.4 & 45.5 & 44.9 & 43.0 \\
Besi & 47.2 & 50.9 & 52.6 & 50.3 \\
Seng & 25.3 & 30.1 & 28.1 & 27.9 \\
Vitamin A & 71.3 & 67.2 & 66.5 & 68.4 \\
Vitamin B & 106.6 & 148.4 & 100.5 & 129.1 \\
Vitamin C & 60.2 & 35.4 & 56.5 & 50.3 \\
\hline
\end{tabular}

Pada pembuatan makanan untuk anakanak, ibu cenderung memberikan nasi kosong (tanpa lauk pauk). Hal ini akan menyebabkan anak-anak kekurangan konsumsi protein dengan mutu baik karena konsumsi protein hanya bertumpu pada protein nabati beras yang kekurangan asam amino lysin. Hasil analisis menunjukkan bahwa tingkat kecukupan energi di ketiga desa masih berkisar 70 persen dengan tingkat kecukupan tertinggi terdapat di Desa Banain (79.4\%). Tingkat kecukupan yang masih rendah (dibawah 50 persen) dijumpai hampir pada semua zat gizi, kecuali vitamin B yang telah lebih dari 100 persen (Tabel 1). Beras merupakan sumber vitamin B yang baik, sehingga kontribusi terbesar vitamin B berasal dari beras.

Pada Tabel 2 tampak bahwa rata-rata konsumsi anak tidak berbeda secara signifikan antara ketiga desa. Berdasarkan tingkat kecukupannya, masih banyak anak yang mengalami defisit energi (< 70\%), yaitu 37.6 persen. Sekitar 75 persen anak juga mengalami defisit protein. Seperti protein, konsumsi besi anak pada umumnya sangat rendah. Hal ini terjadi karena anak sangat jarang mengkonsumsi makanan hewani sebagai sumber protein dan mineral besi. Demikian pula dengan vitamin A. Tabel 3 menunjukkan proporsi anak yang defisit vitamin A lebih dari 50 persen.

\section{Status Gizi dan Kesehatan Anak}

Keragaan status gizi anak tidak berbeda secara signifikan antar desa penelitian baik menurut indikator $\mathrm{BB} / \mathrm{U}, \mathrm{TB} / \mathrm{U}$ maupun $\mathrm{BB} / \mathrm{TB}$ $(p>0.05)$. Namun, dari sebaran keragaan tampak bahwa anak yang berstatus gizi buruk (severe underweight), sangat pendek (severe stunting) dan sangat kurus (severe wasting) paling banyak ditemukan pada anak yang berasal dari Desa Banain (Tabel 3).

Tabel 2. Sebaran Anak Balita menurut Tingkat Kecukupan Zat Gizi

\begin{tabular}{lcccccccc}
\hline \multicolumn{1}{c}{ Tingkat } & \multicolumn{2}{c}{ Sekon } & \multicolumn{2}{c}{ Banain } & \multicolumn{2}{c}{ Tokbesi } & \multicolumn{2}{c}{ Total } \\
\cline { 2 - 8 } \multicolumn{1}{c}{ Kecukupan } & $\mathbf{n}$ & $\%$ & $\mathbf{n}$ & $\%$ & $\mathbf{n}$ & $\%$ & $\mathbf{n}$ & $\%$ \\
\hline Energi & & & & & & & & \\
Kurang (<70\%) & 20 & 40.8 & 20 & 40.0 & 16 & 32.0 & 56 & 37.6 \\
Cukup (70-90\%) & 20 & 40.8 & 15 & 30.0 & 19 & 38.0 & 54 & 36.2 \\
Baik (>90\%) & 9 & 18.4 & 15 & 30.0 & 15 & 30.0 & 39 & 26.2 \\
p-value & 0.967 & & & & & & \\
\hline Protein & & & & & & & & \\
Kurang (<70\%) & 42 & 85.7 & 32 & 64.0 & 37 & 74.0 & 111 & 74.5 \\
Cukup (70-90\%) & 4 & 8.2 & 11 & 22.0 & 8 & 16.0 & 23 & 15.4 \\
Baik (>90\%) & 3 & 6.1 & 7 & 14.0 & 5 & 10.0 & 15 & 10.1 \\
p-value & 0.276 & & & & & & \\
\hline Zat Besi & & & & & & & & \\
Kurang (<70\%) & 42 & 85.7 & 38 & 76.0 & 38 & 76.0 & 118 & 79.2 \\
Cukup (70-90\%) & 5 & 10.2 & 7 & 14.0 & 10 & 20.0 & 22 & 14.8 \\
Baik (>90\%) & 2 & 4.1 & 5 & 10.0 & 2 & 4.0 & 9 & 6.0 \\
p-value & 0.519 & & & & & & \\
\hline Vitamin A & & & & & & & & \\
Kurang (<70\%) & 31 & 63.3 & 25 & 50.0 & 27 & 55.1 & 83 & 56.1 \\
Cukup (70-90\%) & 2 & 4.1 & 13 & 26.0 & 5 & 10.2 & 20 & 13.5 \\
Baik (>90\%) & 16 & 32.7 & 12 & 24.0 & 17 & 34.7 & 45 & 30.4 \\
p-value & 0.828 & & & & & & \\
\hline
\end{tabular}

Tabel 3. Sebaran Status Gizi dan Kesehatan Anak Balita

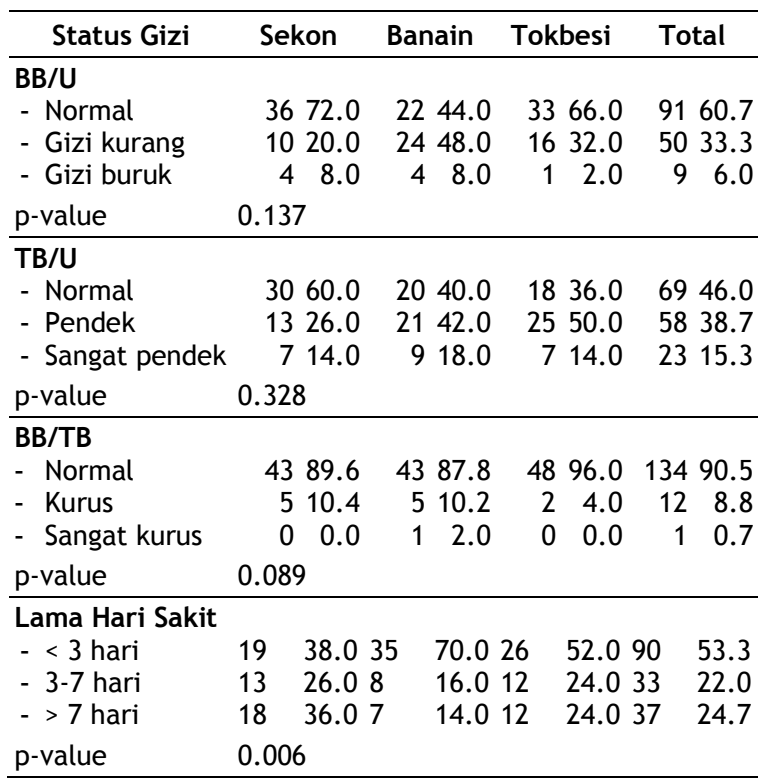

Jika diperhatikan antar kelompok umur, terlihat bahwa penyimpangan nilai z-skor ketiga indikator semakin tinggi seiring dengan semakin tingginya umur anak. Penurunan status 
gizi pada umumnya dimulai ketika anak berumur 6-11 bulan, artinya setelah melewati ASI eksklusif dan memasuki makanan pendamping ASI, keadaan gizi anak semakin memburuk. Kondisi ini diperparah dengan eksposur terhadap lingkungan yang kurang sehat, sehingga peluang terserang penyakit/infeksi yang dapat memperburuk status gizi anak semakin besar.

Sementara dilihat dari sebaran lama hari sakit anak dengan lama hari sakit lebih dari 7 hari dalam dua minggu terakhir paling banyak berasal dari Desa Sekon. Hasil uji menunjukkan perbedaan yang signifikan, dengan rata-rata hari sakit adalah 6.9 hari, sedangkan anak Desa Banain 3.2 hari dan Desa Tokbesi 5.4 hari.

\section{Faktor-Faktor yang Berhubungan dengan Status Gizi Anak}

Gambar 4 menunjukkan bahwa riwayat pemberian ASI dan kebiasaan makan anak berhubungan positif dengan status gizi. Pendidikan ibu yang relatif tinggi meningkatkan pengetahuan gizi serta praktek gizi dan kesehatan, yang secara tidak langsung memperbaiki kebiasaan makan anak, yang pada akhirnya meningkatkan konsumsi energi dan protein serta status gizi anak pada umumnya.

Semakin tinggi pendidikan ibu diikuti oleh semakin mudahnya akses ibu untuk memperoleh informasi tentang gizi dan kesehatan, sehingga berhubungan positif terhadap peningkatan konsumsi energi balita. Kondisi tersebut juga menjelaskan pentingnya pendidikan ibu bagi kualitas gizi anak.
Hanya akses informasi gizi dan kesehatan yang memiliki hubungan positif dan nyata dengan status gizi anak indikator $\mathrm{BB} / \mathrm{TB}$ $\left(r=0.308^{*}\right)$ di Desa Sekon. Hal ini berarti ibu berperan penting dalam menentukan status kesehatan anak, sementara status gizi (BB/TB) dapat menggambarkan status gizi dan kesehatan anak dalam jangka panjang. Oleh karena itu, terbukanya akses informasi dan pelayanan bagi masyarakat akan menjadi faktor strategis dalam mengurangi ancaman terjadinya gizi buruk di Desa Sekon.

Di Desa Banain, tingkat kecukupan energi anak berhubungan dengan total produksi pertanian yang dihasilkan, yang menunjukkan bahwa semakin tinggi total produksi pertanian keluarga diikuti dengan semakin tingginya tingkat kecukupan energi anak. Pengeluaran total juga memiliki hubungan yang signifikan dan positif dengan tingkat kecukupan energi anak, yang mengindikasikan bahwa peningkatan kesejahteraan keluarga akan diikuti oleh peningkatan kecukupan energi yang akan berdampak pada status gizi anak.

Pada Gambar 5 tampak bahwa terdapat dua variabel yang berhubungan signifikan dengan status gizi anak indikator $\mathrm{BB} / \mathrm{U}$, yaitu lingkungan fisik dan sanitasi rumah $\left(r=0.347^{*}\right)$ dan perilaku gizi ibu $\left(r=0.322^{*}\right)$. Sementara itu, status gizi anak indikator BB/TB memiliki hubungan yang signifikan dan positif dengan kebiasaan makan anak $\left(r=0.293^{*}\right)$ dan status gizi anak indikator $\mathrm{TB} / \mathrm{U}$ memiliki hubungan yang signifikan dan positif dengan lingkungan fisik rumah $\left(r=0.372^{* *}\right)$ dan pengetahuan gizi ibu $\left(r=0.408^{* *}\right)$ serta perilaku gizi ibu $\left(r=0.291^{*}\right)$.

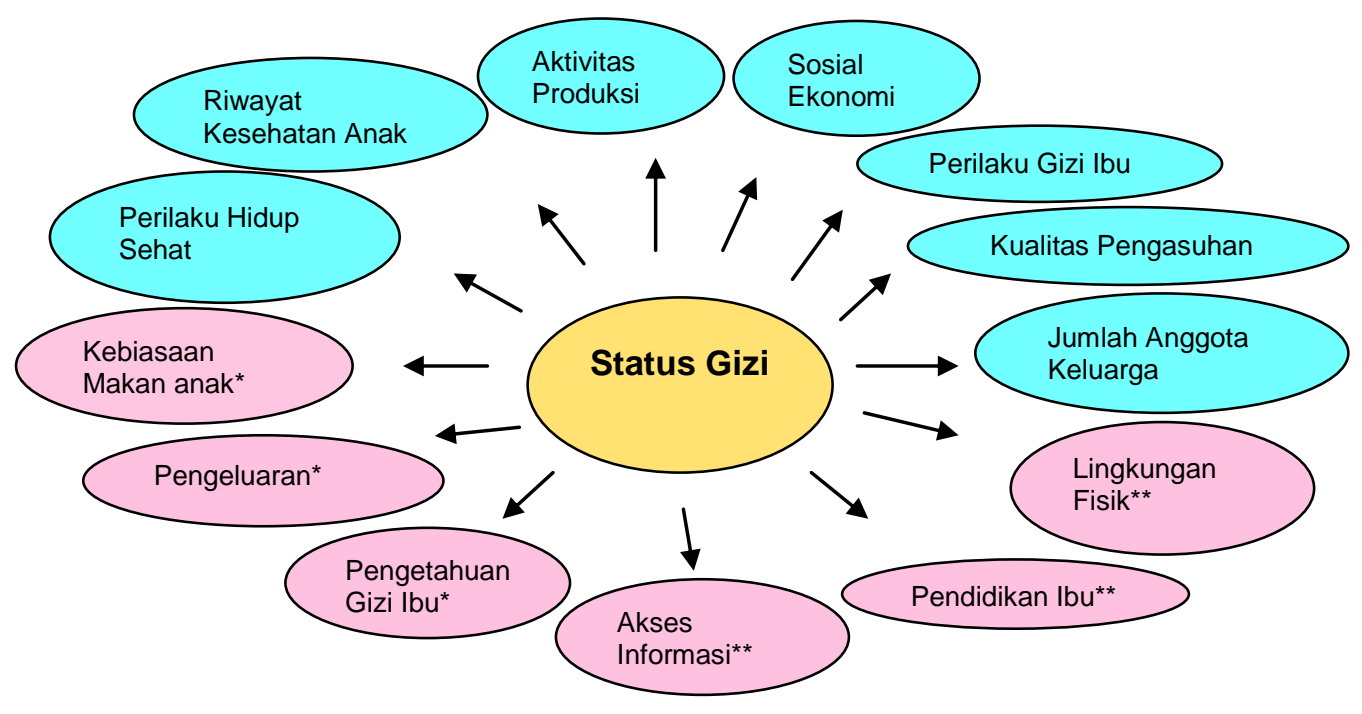

Keterangan: $\operatorname{Sig}^{*}(p<0.1) ; \operatorname{Sig}^{* *}(p<0.05) ; \operatorname{Sig}^{* * *}(p<0.005)$

Gambar 4. Hubungan antar Variabel Independen terhadap Status Gizi Anak Balita di Desa Sekon 


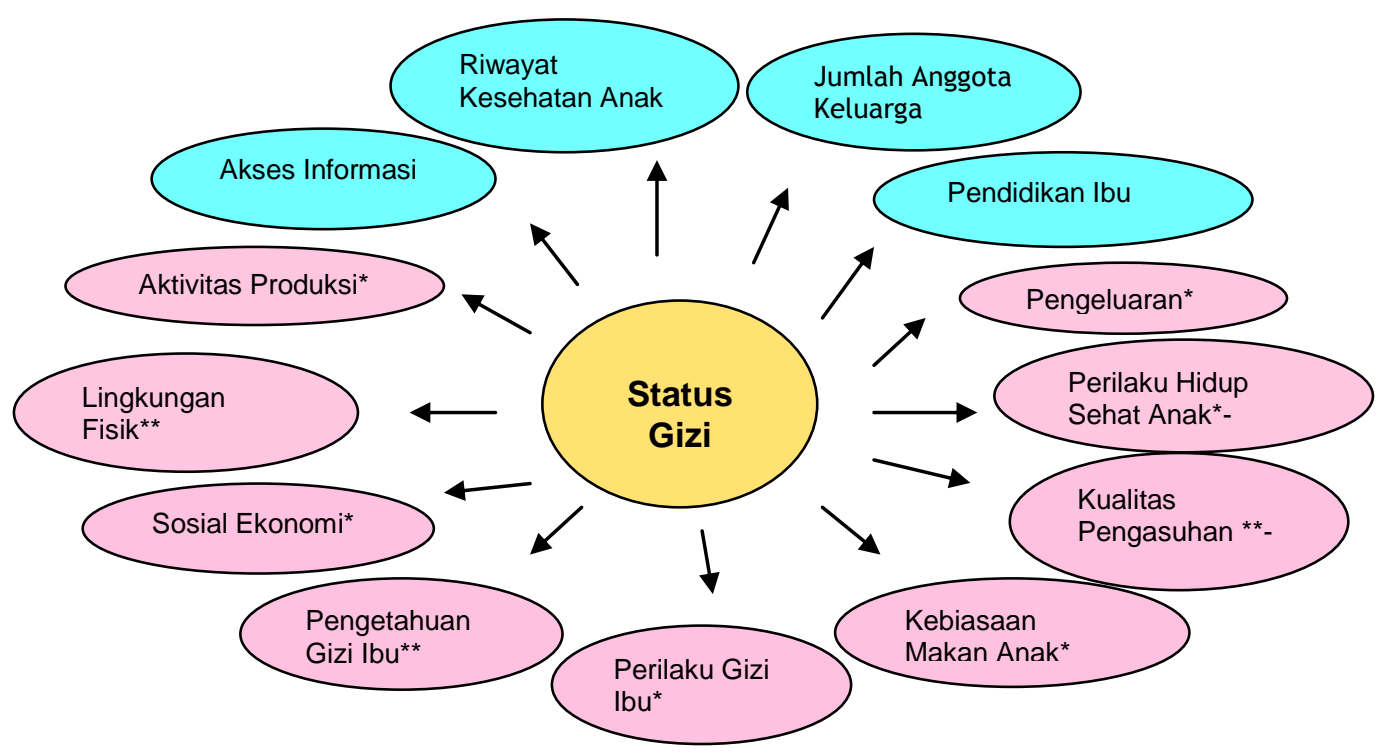

Keterangan: $\operatorname{Sig}^{*}(p<0.1) ; \operatorname{Sig}^{* *}(p<0.05) ; \operatorname{Sig}^{* * *}(p<0.005)$

Gambar 5. Hubungan Antar Variabel Independen terhadap Status Gizi Anak Balita di Desa Banain

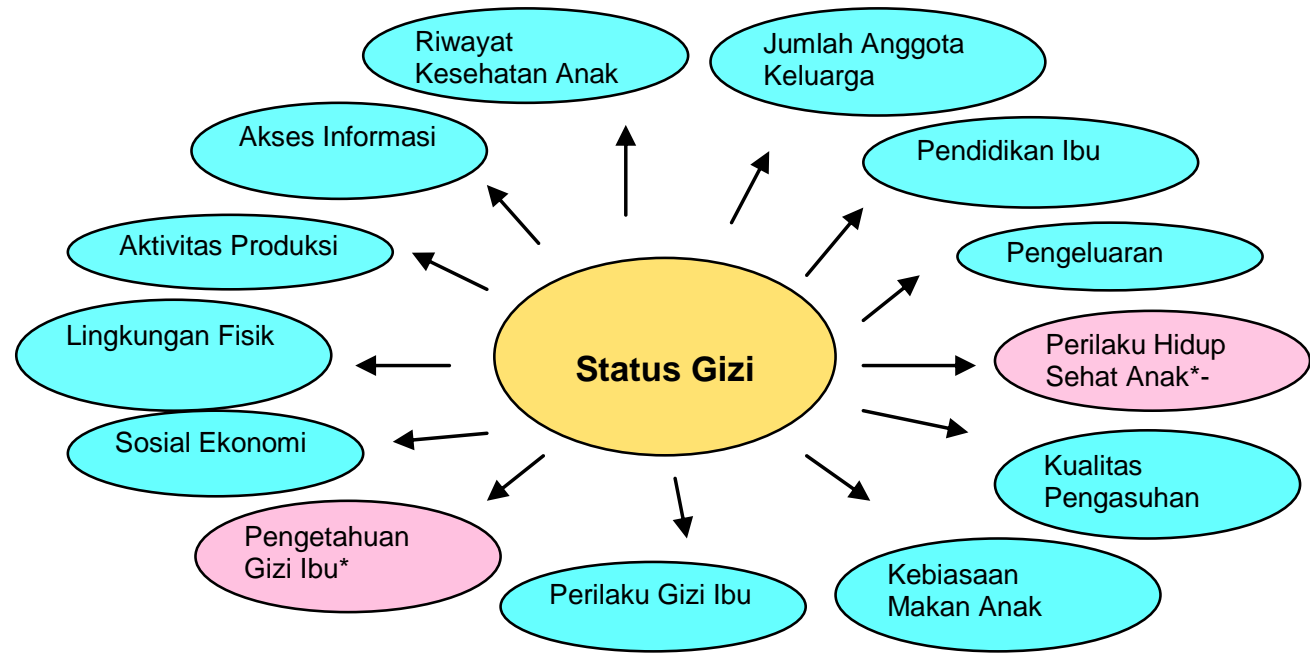

Keterangan: $\operatorname{Sig}^{*}(p<0.1) ; \operatorname{Sig}^{* *}(p<0.05) ; \operatorname{Sig}^{* * *}(p<0.005)$

Gambar 6. Hubungan Antar Variabel Independen terhadap Status Gizi Anak Balita di Desa Tokbesi

Lingkungan fisik rumah (termasuk ketersediaan air bersih) yang baik mengindikasikan baiknya sosial ekonomi keluarga, yang didukung dengan pengetahuan dan perilaku gizi ibu di Desa Banain berperan dalam menentukan status gizi anak. Mengingat minimnya penyediaan air bersih, maka perbaikan sarana penyedia air bersih bagi setiap keluarga menjadi salah satu kunci bagi upaya perbaikan gizi di Desa Banain.

Berbeda dengan dua desa sebelumnya, tidak terdapat variabel yang berhubungan signifikan dengan tingkat kecukupan energi dan protein di Desa Tokbesi. Variabel tersebut diduga berhubungan erat dengan faktor budaya, seperti kebiasaan merokok dan menginang sirih, yang mempengaruhi ketersediaan pangan bagi anak.

Di Desa Tokbesi, perilaku hidup sehat anak dan pengetahuan gizi ibu harus menjadi perhatian dalam upaya perbaikan gizi anak (Gambar 6). Hasil uji statistik menunjukkan korelasi yang signifikan terhadap status gizi anak $\left(r=-0.355^{*}\right.$ dan $\left.r=0.353^{*}\right)$. Pengetahuan gizi ibu dengan demikian perlu terus ditingkatkan agar kemudian diikuti oleh perilaku gizi 
yang baik, kebiasaan makan anak yang tepat, dan perilaku hidup sehat anak yang juga baik. Hasil pengamatan di Desa Tokbesi menunjukkan bahwa perilaku hidup sehat ibu dan anak masih perlu diperbaiki. Oleh karena itu, revitalisasi posyandu dan kader posyandu harus terus dilakukan agar pengetahuan gizi ibu, perilaku gizi ibu, serta kebiasaan makan anak menjadi lebih baik.

\section{KESIMPULAN}

Prevalensi anak balita yang mengalami gizi kurang dan gizi buruk di daerah penelitian masih tinggi, yaitu 33.3 persen mengalami underweight dan 6,0 persen mengalami severe underweight. Sementara itu, anak balita yang memiliki yang memiliki status gizi sangat pendek (severe stunted) dan sangat kurus (severe wasted) masing-masing mencapai 15.3 persen dan 0.7 persen. Persentase tertinggi untuk masalah gizi buruk ini ditemukan di Desa Banain. Terdapat kecenderungan dimana semakin tinggi umur anak, khususnya umur 6 bulan ke atas, penyimpangan status gizi anak terhadap baku status gizi WHO-NCHS semakin melebar ke kiri (status gizi memburuk) yang mengindikasikan buruknya kualitas makanan sapihan dan masalah kesehatan (penyakit/ infeksi) pada anak balita berumur diatas 6 bulan.

Hasil analisis penyebab masalah gizi kurang di daerah penelitian menunjukkan bahwa buruknya status gizi anak balita di: 1) Desa Sekon adalah pendidikan ibu; akses ibu terhadap informasi, khususnya gizi dan kesehatan; pengetahuan gizi ibu, kebiasaan makan anak dan pendapatan (pengeluaran total); 2) Desa Banain adalah pengetahuan gizi ibu, perilaku gizi ibu, lingkungan fisik, kebiasaan makan anak, keadaan sosial ekonomi, khususnya pendapatan (pengeluaran total); serta 3) Desa Tokbesi adalah pengetahuan gizi ibu. Peran ibu sebagai "gate keeper" dalam menjaga konsumsi dan status gizi di rumahtangga nampak sangat menonjol di ketiga desa. Peran itu terlihat dari pengaruh pengetahuan gizi ibu, akses informasi gizi dan kesehatan, praktek gizi \& kesehatan ibu, dan alokasi pengeluaran pangan dan nonpangan (pendapatan).

\section{UCAPAN TERIMAKASIH}

Penulis menyampaikan terimakasih yang mendalam kepada Plan Indonesia beserta staf yang telah membiayai penelitian ini dan banyak memberikan bantuan selama berlangsungnya penelitian ini. Penulis juga sangat berterimakasih kepada para enumerator yang telah membantu dalam pengumpulan dan analisis data.

\section{DAFTAR PUSTAKA}

[DEPKES] Departemen Kesehatan RI. 2008. Laporan Hasil Riset Kesehatan Dasar Propinsi NTT 2007. Badan Penelitian dan Pengembangan Kesehatan, Departemen Kesehatan, Jakarta.

Engel PL, Mennon P, \& Haddad L. 1997. Care and Nutrition: Concept and Measurement. International Food Policy Research Institute, Washington.

Martianto D, Riyadi H, Hastuti D, Briawan D, \& Alfiasari. 2006. Ketersediaan, Konsumsi Pangan dan Status Gizi Anak Balita di Kabupaten Lembata, Provinsi NTT. Fakultas Ekologi Manusia, IPB, Bogor.

Myers RG. 1990. The Twelve Who Survive: Strengthening Programs of Early Childhood Development in the Thirld World. High/Scope Press, Michigan.

Zeitlin M, Megawangi R, Colleta ND, \& Babatunde FD. 1991. Strengthening the Family to Participate in Development. The United Nations University, New York.

[WHO] World Health Organization. 1995. Physical status: the use and interpretation of anthropometry. Report of a WHO Expert Committee. 